\title{
Availability Assessment of China Copper Resources
}

\section{Zhang-huang $\mathrm{YE}^{1,2}$, Yue $\mathrm{LI}^{2}$, Qiang $\mathrm{YAN}^{2}$ and Jia-huan $\mathrm{GUO}^{3}$}

1.Jiangxi Science and Technology Normal University, Nanchang, Jiangxi;

2.Institute of Mineral Resources, Chinese Academy of Geological Sciences, Beijing;

3.China University of Geosciences, Beijing

Corresponding author at chuckverna@sina.com

Keywords: Availability, copper resources, abroad, supply and demand

Abstract. The growth of copper supply capacity cannot keep up with the consumption growth in China, so the copper in China is still in a short supply in the future. The supply capacity of copper mine reduced from $30.7 \%$ in 2000 to $17.4 \%$ in 2013. Due to the late massive use of copper in China, the social recycling of secondary resources will still be in rapid growth. In 2013, the consumption of the scrape copper in China was 4.0472 million tons, representing 35\% of the copper consumption. China's imports of refined copper increased from 1.6\% in 1994 to 37.6\% of global imports in 2010. China's imports of copper concentrate rose from 5.9\% in 1995 to $37.95 \%$ in 2013 of global imports. In 2013, China's imports of scrape copper arrived at 2.0653 million tons (metal amount), accounting for $18 \%$ of China total copper consumption. Among the top 20 copper mines around the world, there are eight copper mines in Chile.

\section{Introduction: Supply-demand Analysis of China's Copper Before 2030}

Availability assessment of China copper resources is vitally important, because the copper in China is still in a short supply in the future. Copper will become one of the mineral products with the highest dependency and the grimmest situation (Table 1).

Table 1 Future Trend of Copper Supply and Demand in China

\begin{tabular}{|c|c|c|c|c|c|c|}
\hline Category & unit & 2010 & 2015 & 2020 & 2025 & 2030 \\
\hline Demand & $\begin{array}{c}\text { Ten thousand } \\
\text { tons(metal) }\end{array}$ & 680 & 1033 & 1331 & 1489 & 1345 \\
\hline Self-production & $\begin{array}{c}\text { Ten thousand } \\
\text { tons(metal) }\end{array}$ & 116.0 & 140 & 170 & 185 & 200 \\
\hline recycled copper & $\begin{array}{c}\text { Ten thousand } \\
\text { tons(metal) }\end{array}$ & 68.0 & 155 & 266 & 372 & 404 \\
\hline Import & $\begin{array}{c}\text { Ten thousand } \\
\text { tons(metal) }\end{array}$ & 496.0 & 738 & 895 & 932 & 742 \\
\hline $\begin{array}{c}\text { Foreign } \\
\text { dependence }\end{array}$ & $\%$ & 72.9 & 71.4 & 67.2 & 62.6 & 55.1 \\
\hline output/demand & $\%$ & 17.1 & 13.6 & 12.8 & 12.4 & 14.9 \\
\hline
\end{tabular}

It is predicted that China's copper demand still will maintain a rapid growth. In the reference mode, copper demand will reach 10.33 and 13.31 million tons in 2015 and 2020 respectively. It will peak around 2025 with copper demand of 14.89 million tons. Then, it will have a slow descending tendency. In 2030, the copper demand will fall to 13.45 million tons. The peak of copper demand in China will arrive from 2022 to 2025 with the amount of 14 million tons to 16 million tons.

\section{The Supply Assessment of Copper Mine in China}

China is short of copper mineral resources, which have been one of mineral resources with high foreign dependence. The growth of supply capacity cannot keep up with the consumption growth for being subject to conditions. The supply capacity of copper mine reduced from $30.7 \%$ in 2000 to 
$17.4 \%$ in 2013, while the proportion of Chinese copper consumption in the world grew from $12.7 \%$ in 2000 to $46.8 \%$ in 2013.

The reserves of copper mineral resources in China reaches 93.509 million tons with 27 year static guarantee period if calculated by $50 \%$ of reserves conversion rate. The output of Jiangxi, Yunnan, Inner Mongolia and Anhui accounted for 58.67\% of total output in 2011. But the guarantee level of resources reserves in these four provinces is pretty low with reserve-production ratio respectively being 15, 11, 4 and 9 . And the guarantee level of the four provinces is all below national average, and it is unlikely to improve the supply capacity greatly. Among other provinces, Tibet owns the highest growth potential of supply capacity. The reserves resources of copper mine in Tibet takes up $21.69 \%$ of total reserves. Only taking resources into account, Tibet owns great growth potential of supply capacity. But its natural conditions and ecological environment limit the exploitation of resources.

\section{The Supply Assessment of Secondary Copper in China}

Before the 90s, a wide network of recycling scrape metals and waste materials was established all over the country, and the scrape copper recycling was also included in the plan.

In line with different production stages, the scrape copper can be divided into disposable scrape copper, new scrape copper and old scrape copper. There are two methods of recycling the scrape copper in China, that is, direct utilization and indirect utilization.

In 2013, the consumption of the scrape copper (home-made scrape copper and imported scrape copper) in China was 4.0472 million tons, representing 35\% of the copper consumption. China kept up with the world average level but still lagged far behind the developed countries in the utilization ratio of the scrape copper. The experience of US shows that the social recycling amount of secondary resources will grow rapidly after the large-scale input of first resources for 50 years (Figure 1). When accumulative amount reaches a high level, the social recycling amount will increase at a lower speed, entering the slow growth period. Due to the late massive use of copper in China, the social recycling of secondary resources will still be in rapid growth.

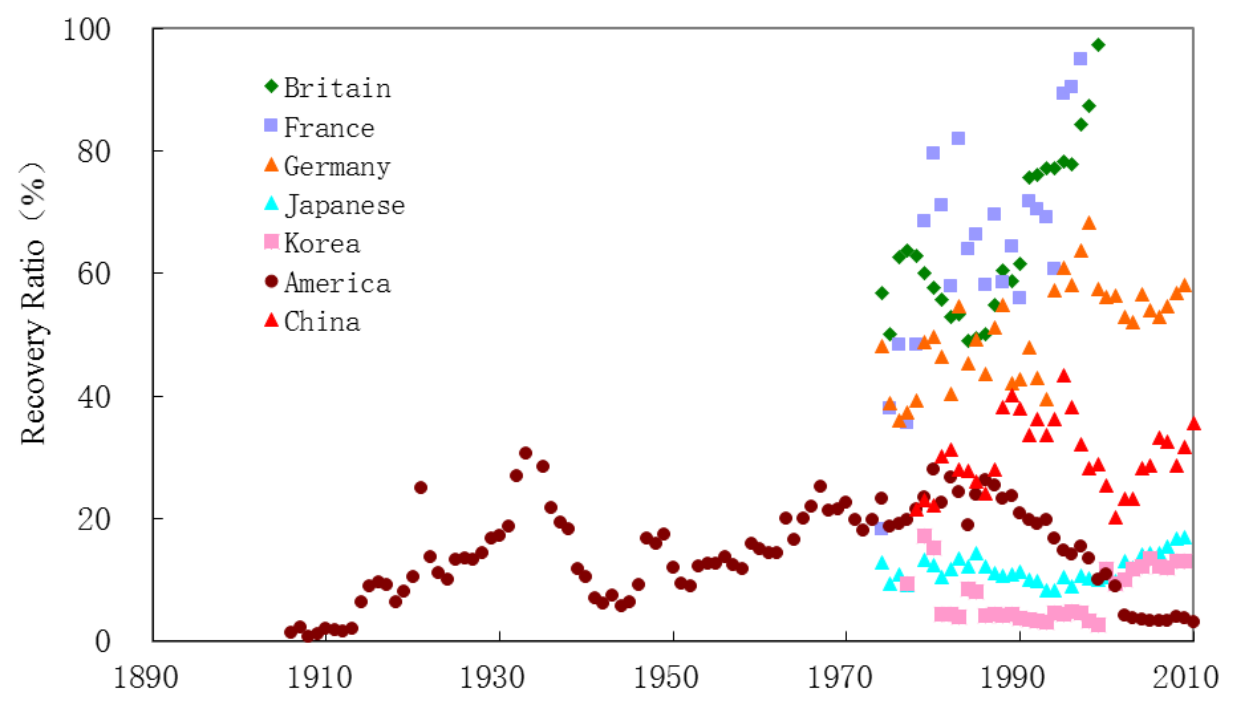

Figure 1. The Proportion of Secondary Copper Recycling in Major Countries (\%)

Data Sources: World Metal Statistics Yearbook, WBMS

\section{The Assessment of China's Dependence on Foreign Primary Copper}

In 2002, China's imports of refined copper surpassed the US for the first time to become the world's largest importer of refined copper; in 2009, China's imports of copper concentrate exceeded Japan to be the world's largest importer of copper concentrate. The imports of refined copper increased from 0.0723 million tons in 1994 to 2.9204 million tons in 2010, and the proportion also 
grew from 1.6\% in 1994 to 37.6\% of global imports in 2010 (Figure 2).

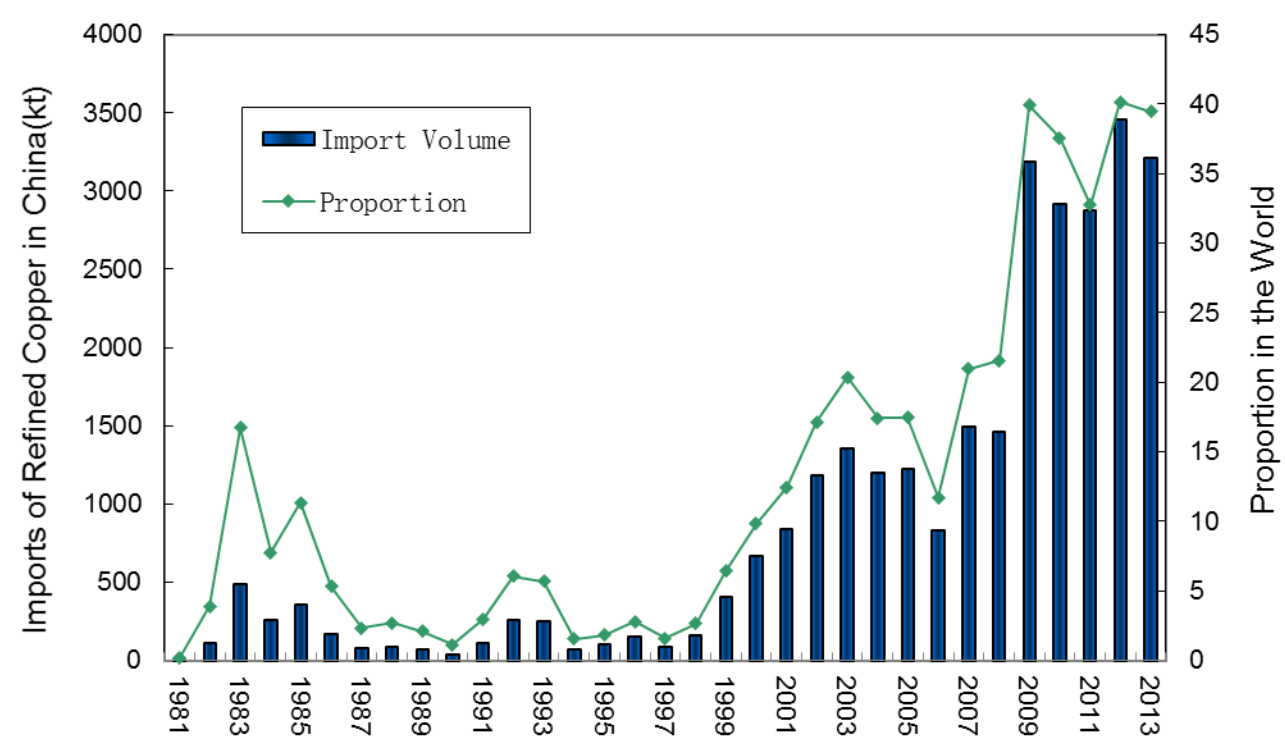

Figure 2. Imports of Refined Copper in China and Its Proportion in the World

Data Sources: WBMS, China Nonferrous Metals Industry Association

In 2013, imports of refined copper mainly came from Chile, occupying one third of the total imports (Table 2).

Table 2 Imports of China's Refined Copper in 2013 (unit: ten thousand tons )

\begin{tabular}{|c|c|c|c|c|c|c|c|c|}
\hline & Chile & Japan & India & Australia & Kazakhstan & Zambia & Korea & $\begin{array}{c}\text { Other } \\
\text { Countries }\end{array}$ \\
\hline imports & 106.76 & 24.04 & 23.99 & 23.62 & 19.75 & 16.04 & 14.71 & 98.38 \\
\hline proportion & $33.23 \%$ & $7.48 \%$ & $7.47 \%$ & $7.35 \%$ & $6.15 \%$ & $4.99 \%$ & $4.58 \%$ & $28.75 \%$ \\
\hline
\end{tabular}

Data Source: China's General Administration of Customs

Our imports of copper concentrate rose from 0.1211 million tons in 1995 to 2.52 million tons in 2013 with the proportion growing from 5.9\% in 1995 to 37.95\% in 2013 of global copper concentrate import (Figure 3).

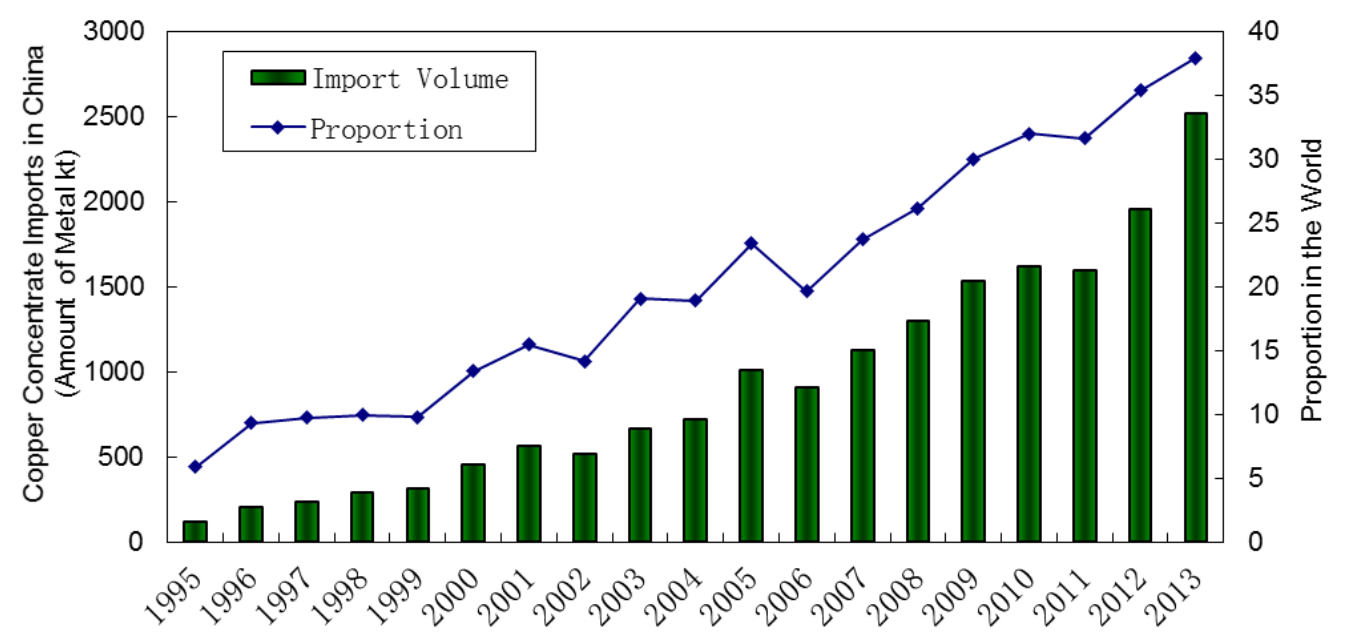

Figure 3. Imports of Copper Concentrate in China and Its Proportion in the World Data Sources: WBMS, China Nonferrous Metals Industry Association

\section{The Assessment of China's Dependence on Foreign Secondary Copper}

In 2013, China's imports of scrape copper arrived at 2.0653 million tons (metal amount), accounting for $18 \%$ of China total copper consumption. According to statistics from China's General Administration of Customs, real imports of scrape copper reached 4.3726 million tons 
(physical quantity). The main importing countries were industrial developed countries and those with high environmental requirements (Table 3).

Table 3 Imports of China's Scrape Copper in 2013 (physical quantity)

\begin{tabular}{|c|c|c|c|c|c|c|c|c|}
\hline $\begin{array}{l}\text { (ten } \\
\text { thousand } \\
\text { tons) }\end{array}$ & America & Spain & Germany & Australia & Malaysia & Japan & Holland & $\begin{array}{c}\text { Other } \\
\text { countries }\end{array}$ \\
\hline imports & 96.41 & 47.05 & 39.88 & 37.62 & 35.79 & 27.65 & 26.57 & 126.27 \\
\hline proportion & $22.05 \%$ & $10.76 \%$ & $9.12 \%$ & $8.60 \%$ & $8.19 \%$ & $6.33 \%$ & $6.08 \%$ & $28.88 \%$ \\
\hline
\end{tabular}

Data Source: China's General Administration of Customs

Before the 1990s, the China copper smelting was mainly based on domestic market, and imports of scrape copper were very few. After the 1990s, with the significant improvement of recycling technology, the establishment of pretreatment base and remarkable profits by recycling the scrape copper, imports of scrape copper rose rapidly from 0.0217 million tons in 1990 to 5.5769 million tons(physical quantity) in 2008. Calculated by 30\% of copper content, China imported 1.68 million tons of copper in the form of scrape copper in 2008, which was pretty considerable. Whereas, influenced by financial crisis and falling copper prices, imports of scrape copper decreased to 4 million tons ( physical quantity) in 2009 but increased to 4.3725 million tons in 2009 (Figure 4).

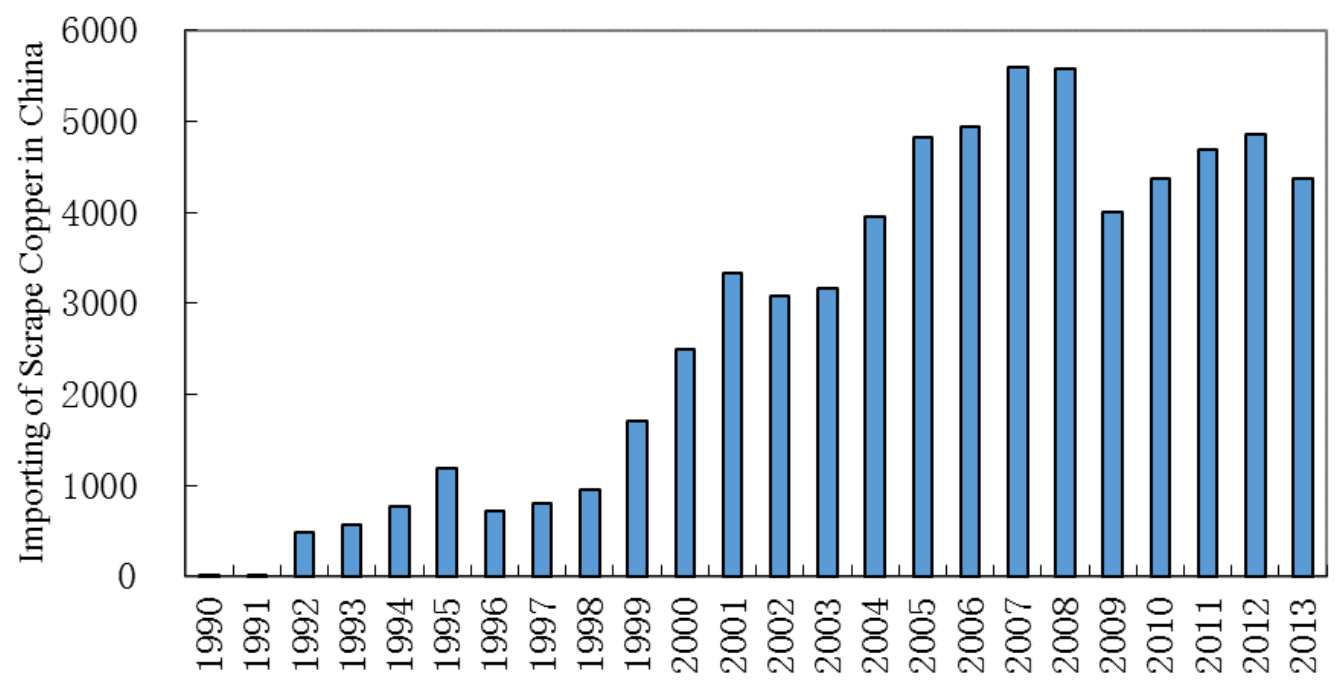

Figure 4. The Importing Scrape Copper in China (physical quantity)

Data Source: China Nonferrous Metals Industry Association

\section{The Analysis of Supply Capacity of Foreign Copper Mine}

Among the top 20 copper mines around the world, there are eight copper mines in Chile, that is, Escondida, Codelco Norte, Collahuasi, Los Pelambres, El Teniente, Andina, Los Bronces and Spence. The production capacity of these eight copper mines amount to 4.34 million tons, accounting for $53.2 \%$ of the total production capacity of top 20 copper mines; there are two in Indonesia: Grasberg and Batu Hijau, both of whose production capacity respectively arrive at 0.75 million tons and 0.25 million tons. Besides, Russia, Peru, Zambia, Kazakhstan, Australia, Poland, Iran, Mexico each has one copper mine entering the top 20 copper mines in the world.

Among the major copper mine companies in Chile, as an open-pit copper mine with the highest annual output all over the globe at present, Escondida Mine produces $8 \%$ of the global copper mine. This copper mine is regarded as a porphyry type. Spence Mine owns the highest grade of $1.46 \%$.

Located in Irian Jaya of Indonesia, Grasberg Mine mainly contains porphyry and skarn type copper. And this copper mine has the world's second largest copper reserves with 0.28 billion tons of ore reserves and $1.09 \%$ of average copper grade. 


\section{References}

[1] United Nations, Handbook of World Trade Statistics, 1992-2013

[2] Wang Anjian, Wang Gaoshang, Chen Qishen, etc. 2010. The Mineral Resources Demand Theory and the Prediction Model[J]. Acta Geoscientica Sinica, 31(2):137-147

[3] Copper Development Association Inc, Annual Data 2014, Copper Supply and Consumption 1980-2013. http://www.copper.org/

[4] World Bureau of Metal Statistics, World metal statistics yearbook, 1984-2013. London: World Bureau of Metal Statistics

[5] Wang Anjian, Wang Gaoshang, Zhang Jianhua, etc. 2002. Mineral Resources and National Economy Development [M]. Beijing: Seismological Press

[6] Copper Development Association Inc, Annual Data 2014, Copper Supply and Consumption 1980-2013. http://www.copper.org/

[7] Wang Anjian, Wang Gaoshang, Zhang Jianhua, etc. 2002. Mineral Resources and National Economy Development [M]. Beijing: Seismological Press 